\section{INHALED FOREIGN BODIES}

BY

\section{L. N. ROBINSON, M.D., F.R.C.S., F.R.C.S.(C).}

AND

WILLIAM W. MUSHIN, M.B., F.F.A.R.C.S., D.A. From the Sully Hospital Thoracic Centre, Glamorganshire

The problems associated with inhaled foreign bodies usually receive little attention in the medical curriculum and in textbooks. This is in contradistinction to the ingested foreign body, which is well documented at every stage of its journey. The importance of the inhaled foreign body is demonstrated by the RegistrarGeneral's (1954) statistics for deaths in England and Wales from this cause. There were 11 due to inhalation, as compared with 29 due to ingestion (Tables I and II).

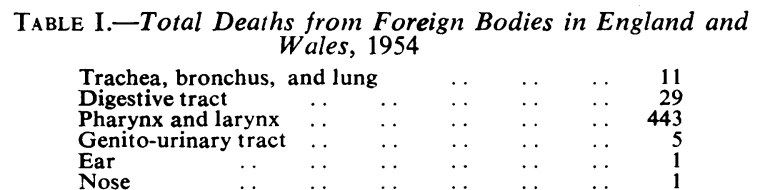
Wales, 1954

Trachea, bronchus, and lung

Digestive tract

Pharynx and larynx

Genito-urinary tract

Ear

Nose

TABLE II.-Ages of 11 Subjects who Died From Inhaled Foreign Bodies in Trachea, Bronchi, and Lungs in England and Wales in 1954

\begin{tabular}{l|c|c|c|c|c|c|c|c|c|c}
\hline Age: & -1 & -5 & -15 & -25 & -35 & -45 & -55 & -65 & -75 & -85 \\
No. & 4 & 1 & 0 & 0 & 0 & 1 & 1 & 1 & 1 & 2 \\
\hline
\end{tabular}

A foreign body may be overlooked in diagnosis for many reasons. The highest incidence is in children who are too young to give a history (Fig. 1). The typical

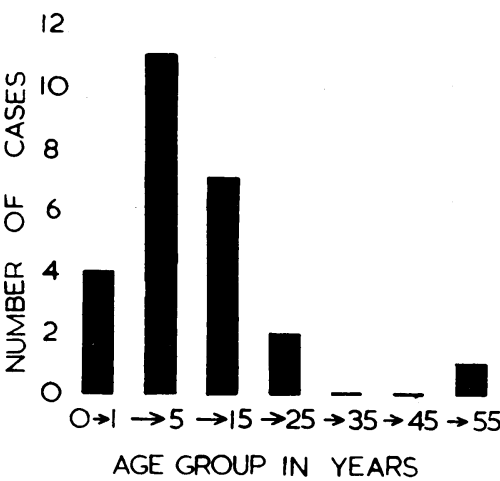

FIG. 1.-Age incidence of cases. early history of choking while eating, accompanied by dyspnoea and cyanosis, or of eating while playing and $\mathrm{then}$ choking, may not be known by a parent when further symptoms develop. This is particularly liable to happen if the child is on holid a y or being tended by a baby-sitter when the foreign matter is inhaled (Table III, Cases 5 and 12). Again, a patient may choke and cough, and think that the object has been expelled, whereas in fact it has been inhaled from a larger sensitive tube to a smaller insensitive one (Case 8). Further, a small metallic foreign body may not cause any immediate disturbances, and only come to light years later from its pressure effects (Case 2). An object may also be inhaled when a patient is asleep, under the influence of alcohol, during an epileptic seizure, or during anaesthesia (Case 15). The foreign body is often thought to have been swallowed and that it will be passed by the bowel. Sometimes the early history is not known, and the presenting symptoms may simulate those of bronchitis, pneumonia, tumour, lung abscess, bronchiectasis (Case 6), tuberculosis, or empyema (Coope, 1948)

\section{Protective Reflexes}

The inhaled object may stimulate the laryngeal mucosa and cause adduction of the cords. The patient chokes and coughs, and may expel the object. A large object which is not dislodged will cause complete obstruction of the larynx and death from asphyxia in a few minutes.

The cough reflex is normally protective for the trachea and bronchi, but each cough is preceded by a deep inspiration, and at this time, before the burst of explosive coughing, the object may be inhaled into the trachea. From here the further passage depends on the size and sharpness of the object. The tendency is for it to be inhaled as far as its size and shape will allow it to go.

If it is large, it will remain in the trachea, causing paroxysms of coughing; as it moves up and down and strikes the glottis from below it makes an "audible slap." If the movements are forcible in the trachea they may be easily perceptible as a "thud" or, if less forcible, as a "flutter" (Jackson and Jackson, 1950).

A smaller foreign body will pass into the right bronchus more commonly than the left, because of the larger diameter and the less acute angle at which this bronchus leaves the trachea. The posterior segmental bronchi are more commonly affected than the anterior.

\section{Pathology}

The nature of the foreign body determines the degree of further reaction. Metallic foreign bodies cause very little immediate inflammation, but in the course of time they become oxidized and the edge roughens, with consequent penetration and pressure. Organic substances such as nuts and beans cause an intense inflammation with oedema, granulations, and pus due to the contained fatty acids. As the material absorbs moisture and swells it progressively blocks the lumen of the passage in which it lodges. The younger the patient the more dangerous it is.

A foreign body lodging in a bronchus may occlude it either completely or partially. Complete obstruction is followed by atelectasis of the portion of the lung supplied by that bronchus (Asherson, 1953). Subsequently the inflammatory changes may take the form of pneumonia, bronchiectasis, lung abscess, and empyema. Partial obstruction may either allow relatively easy passage of air in both directions, in which case the later effects are due to local inflammation only, or it may take the form of a ball-valve obstruction. Air enters the lungs during inspiration when the bronchus dilates, but cannot pass out in the reverse direction during expiration because the bronchial mucosa becomes approximated to the sides of the foreign body. This results in obstructive emphysema.

Occasionally, combinations of these features occur. When a foreign body causes atelectasis of a lobe the remainder of that lung may become "emphysematous" even though it is not directly affected by the object. This is a process of " compensatory emphysema."

\section{Diagnosis}

The original accident is often dramatic, accompanied by choking, prolonged coughing, cyanosis, and dyspnoea. It cannot be overemphasized that such a history should be sought repeatedly from parents, guardians, and baby-sitters. Occasionally, however, a foreign body is inhaled into a distal bronchus without setting up any reflex during its passage. The diagnosis of metallic foreign body is easy, for, although it may cause few signs apart from those of bronchitis, it is clearly seen in either a postero-anterior or lateral radiograph. The diagnosis of a non-opaque foreign body can be made from physical examination. The presence of atelectasis will be shown by diminished movement, dullness to percussion, decreased air entry, with the trachea and apex 
beat perhaps displaced to the same side and the diaphragm high (Fig. 2). Obstructive emphysema is characterized by decreased movement, overexpansion of the affected part of the chest, a hyperresonant or tympanitic percussion note, and poor breath sounds, except in the early case when air is still entering in the inspiratory phase. Clinically this may be mistaken for pneumothorax, but radiographs taken in inspiration and expiration are diagnostic. A comparison of these two pictures shows the shift of the mediastinum away from the affected side on expiration, and the flattened diaphragm, with of course some lung markings in the emphysematous area (Fig. 3). The contrast in transparency of the two sides is not so evident on inspiration, for the compensatory increased movement of the sound lung fills it so well with air that there may be little difference between the translucencies of the two sides.

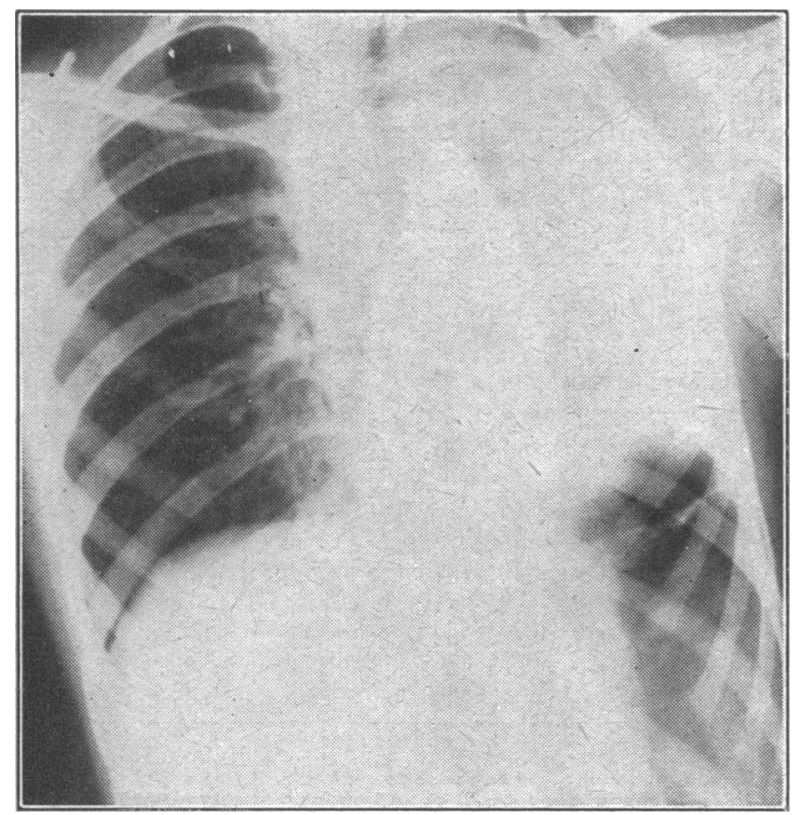

FIG. 2.-Case 4. Postero-anterior chest radiograph: atelectasis of left lung, with mediastinum drawn to the same side, high diaphragm, crowding of ribs, and ground-glass appearance of lung field.

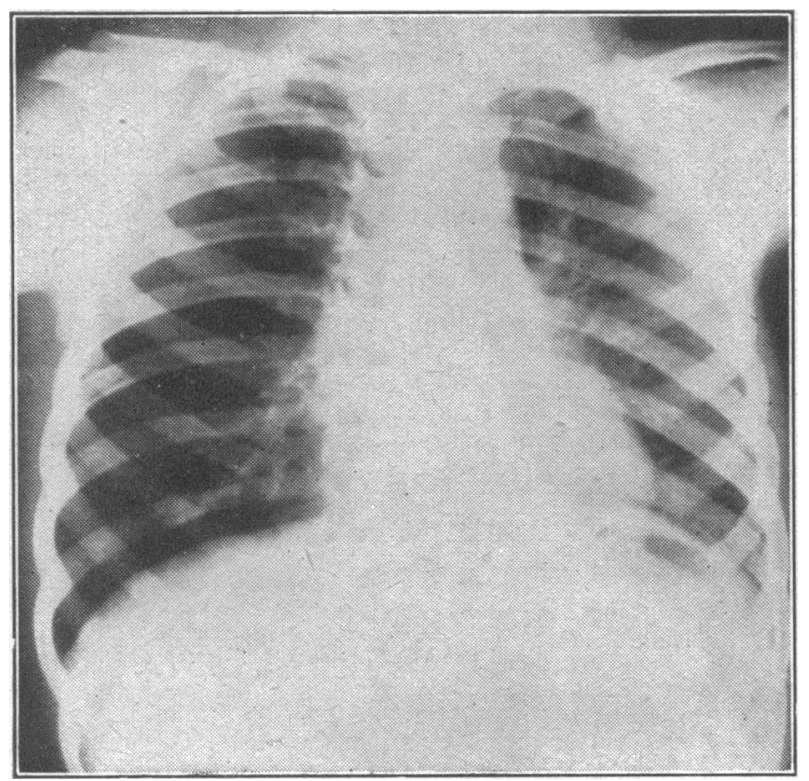

FIG. 3.-Case 8. Postero-anterior chest radiograph: obstructive emphysema right lung, with mediastinum to opposite side, diaphragm depressed, and greater transradiancy of lung.

\section{Differential Diagnosis}

The differential diagnosis may be difficult if the history of inhalation is not obtained. Or if it is obtained and a foreign body is suspected the signs of laryngo-tracheitis per se will simulate those of a foreign body. This happened in a case not reported in this series:

A child went to bed sucking a boiled sweet, and was heard to cough and choke later. Although it had signs of laryngeal stridor and bronchospasm, there were none of localized obstruction radiologically. The child was prepared for bronchoscopy, but before the scope was introduced the cords were seen to be oedematous. This was thought (and proved) to be sufficient to cause the symptoms. The symptoms subsided with nursing in a steam tent and the administration of antibiotics.

Pressure on the bronchi from without, due, for example, to enlarged lymph nodes or mediastinal abscess, may give a clinical picture similar to that of inhaled foreign body. A good example is a foreign body lodged in the oesophagus, which may press on the trachea and cause partial obstruction.

If there is a reasonable likelihood of a non-opaque foreign body being in the air passages in a patient suffering from bronchiectasis, unresolved pneumonia, lung abscess, or obstructive emphysema he should have the benefit of a direct inspection of the air passages by an experienced bronchoscopist.

\section{Treatment}

The hope that a foreign body may be coughed up is unjustifiable, for this course of events occurs in only $3 \%$ of cases (Jackson and Jackson, 1950). The practice of inverting the patient and shaking him to displace the object is dangerous, for the object may move, become impacted in the glottis, and cause suffocation. It is imperative that a skilled bronchoscopist should remove the foreign body as soon as possible, under anaesthesia administered by a competent anaesthetist. There is one caution to this rule : if a child has had unsuccessful attempts at bronchoscopic removal when first seen, and is suffering from laryngeal oedema, this should be treated first and time allowed for the oedema to subside before another attempt is made (Case 3).

\section{Anaesthesia}

The importance of expertly administered anaesthesia for the successful removal of foreign bodies from the respiratory tract cannot be overemphasized. As Fig. 1 shows, the majority of our patients were infants and children, in whom it is notoriously difficult to administer safely an efficient anaesthetic for bronchoscopy. Several of our patients (Cases $1,3,8,9,11$, and 15) had had previous unsuccessful attempts at removal of the object by bronchoscopy, probably necessitated by inefficient anaesthesia. Many of them suffered from anoxia of varying degree, sometimes with gross respiratory obstruction. Anaesthesia must provide the bronchoscopist with a tranquil oxygenated patient in whom all the tracheal and bronchial reflexes have been eliminated so that as much time as is needed can be spent in finding. seeing, and removing the foreign body.

We condemn as unsafe the use of relaxants to obtund respiratory tract reflexes in these circumstances. Suppression of these reflexes by this means occurs coincidentally with respiratory arrest. Unless the surgeon is interrupted continually by the need to ventilate the patient, serious and possibly fatal oxygen lack follows. We know of deaths that have occurred in this way. Surface analgesia with cocaine or, if desired, a similar but longer-lasting drug, forms the essential basis of the method of anaesthesia which we recommend. In adults unconsciousness is rarely indicated. Sedation with papaveretum and hyoscine followed by careful surface analgesia of the pharynx, larynx, and trachea is generally adequate.

Children below the age of 10 years are anaesthetized in a manner similar to that which we use for bronchography (Mushin and Lake, 1951). They are put to sleep in bed with a suitable dose of basal narcotic such as rectal bromethol. 
In the theatre, anaesthesia is slowly and carefully induced with trichlorethylene and oxygen. When laryngoscopy is possible the cords and pharynx are sprayed with local analgesic, and a further $1 \mathrm{ml}$. of solution is injected through a fine catheter into the trachea.

Overdose with local analgesics is a possible danger, and is avoided by carefully limiting the dose used (Mushin and Lake, 1951). Anaesthesia is maintained with a stream of nitrous oxide, oxygen, and trichlorethylene into the side tube of the bronchoscope.

At the end of the operation, and when the bronchoscope has been removed, the child is carefully watched in case laryngeal spasm occurs. This is liable to happen when the operation has lasted longer than expected and the effect of the local analgesic is wearing off. Children are not allowed to leave the operating theatre until free respiration is present.

\section{Bronchoscopy}

Bronchoscopic removal of foreign bodies in children is specially hazardous. The patient usually has a degree of laryngospasm and bronchospasm, and if these become extreme during the procedure the bronchoscope must be immediately withdrawn as the first step in overcoming it. Needless to say, manipulations must be gentle. Because a small instrument is necessary, the grasping of the foreign body in children is always "blind" -not an easy accomplishment with an elusive object. The risk of dropping an object on which a tenuous hold is maintained is considerable: the seriousness of this accident might be imagined if an object is being removed from an atelectatic lung and it drops into the opposite main bronchus. For this reason the table should be kept tilted in a slight Trendelenburg position, and a portable $x$-ray machine should be available in the theatre. The instruments which have been used routinely are shown in Fig. 4.

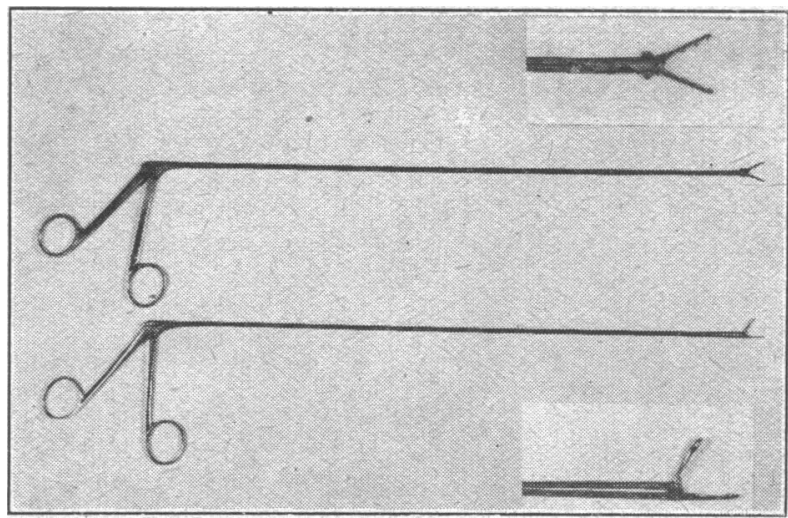

Fig. 4.-Photograph of two instruments used for removing foreign bodies from bronchus. (Made by Thackrays from German model by $\mathbf{H}$. Pfau.)

When the object has been grasped the forceps and the bronchoscope are removed simultaneously in a smooth motion, so that the object will not be dropped at the point where it may catch-the cords, the epiglottis, and the back of the tongue. Repeated attempts at removal of fragile objects-for example, nuts-may be necessary, and occasionally smaller pieces may be removed with a sucker. Sharp objects whose points are uppermost should be manipulated so that the sharp end is protected in the beak of the bronchoscope; with safety-pins the point is drawn into the scope and the "keeper" may safely trail (Fig. 5)

After removal, an $x$-ray film is taken on the table, and if all the material has come away the film will show a dramatic improvement in any previous obstructive emphysema or atelectasis. If there is still some slight evidence of retention of fragments the patient is encouraged to cough before

TABLE III.-Summary of Cases

\begin{tabular}{|c|c|c|c|c|c|c|c|}
\hline $\begin{array}{l}\text { Case } \\
\text { No. }\end{array}$ & $\begin{array}{l}\text { Age in } \\
\text { Years }\end{array}$ & Sex & $\begin{array}{l}\text { Duration of } \\
\text { Symptoms }\end{array}$ & $\begin{array}{l}\text { History } \\
\text { and Examination }\end{array}$ & $\begin{array}{c}X \text {-ray } \\
\text { Findings }\end{array}$ & $\begin{array}{c}\text { Findings } \\
\text { at Bronchoscopy }\end{array}$ & Comment \\
\hline 1 & 12 & $\mathbf{M}$ & 8 days & $\begin{array}{l}\text { Inhaled dressmaker's pin which he } \\
\text { had in mouth while watching an } \\
\text { aeroplane }\end{array}$ & $\begin{array}{l}\text { Pin deeply placed } \\
\text { in basal seg- } \\
\text { ment R.L.L. } \\
\text { (Fig. 6) }\end{array}$ & $\begin{array}{l}\text { Attempt to remove it broncho- } \\
\text { scopically elsewhere failed, } \\
\text { in spite of using magnet and } \\
\text { obtaining "radiological" } \\
\text { contact with pin }\end{array}$ & $\begin{array}{l}\text { Right thoracotomy, attempt to } \\
\text { remove pin by bronchotomy } \\
\text { at basal stem bronchus } \\
\text { failed; pin then pushed out } \\
\text { through visceral pleura }\end{array}$ \\
\hline 2 & 25 & $\mathbf{F}$ & 12 months & $\begin{array}{l}\text { Frequent chest colds with mucoid } \\
\text { sputum. Consequently recalled } \\
\text { swallowing or inhaling safety-pin } \\
\text { at a party } 17 \text { years previously }\end{array}$ & $\begin{array}{l}\text { Open safety-pin } \\
\text { R.M.B.(Fig. 5) }\end{array}$ & $\begin{array}{l}\text { Pin in R.L.M.B., surrounded } \\
\text { by granulation tissue. Re- } \\
\text { moved easily, keeper trailing }\end{array}$ & Cough subsided in one week \\
\hline 3 & 17 & $\mathbf{M}$ & 9 days & $\begin{array}{l}\text { Definite history of inhaling foreign } \\
\text { body. Previous bronchoscopy at } \\
\text { another hospital unsuccessful. Con- } \\
\text { siderable laryngeal stridor. T. } \\
101^{\circ} \text { F. }\left(38 \cdot 3^{\circ} \text { C.); P. 130;R. } 36\right.\end{array}$ & $\begin{array}{l}\text { Atelectasis of } \\
\text { basal segments } \\
\text { R.L.L. }\end{array}$ & $\begin{array}{l}\text { Two attempts at bronchosco- } \\
\text { pic removal, the second } \\
\text { successful in extracting } \\
\text { granite chip from R.M.B. }\end{array}$ & $\begin{array}{l}\text { First bronchoscopy delayed } 2 \\
\text { days after admission and } \\
\text { second one for } 5 \text { days. } \\
\text { Nursed in steam tent }\end{array}$ \\
\hline 4 & 8 & $\mathrm{~F}$ & $2 "$ & 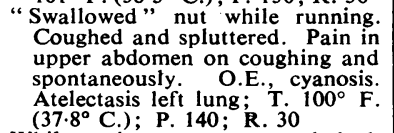 & $\begin{array}{l}\text { Atelectasis and } \\
\text { consolidation } \\
\text { left lung (Fig. } \\
\text { 2) }\end{array}$ & $\begin{array}{l}\text { Part of nut and shell removed } \\
\text { from L.M.B. Mucopus dis- } \\
\text { tal to this aspirated }\end{array}$ & $\begin{array}{l}\text { Slow expansion apical segment } \\
\text { L.L.L.; but complete in } \\
7 \text { days }\end{array}$ \\
\hline 5 & $y$ & $\mathrm{~F}$ & 24 hours & $\begin{array}{l}\text { While eating raw carrot, choked, } \\
\text { became dyspnoeic and wheezy, } \\
\text { (history obtained from "sitter" } \\
\text { one day later). O.E., cyanosed and } \\
\text { very dyspnoeic. Obstructive em- } \\
\text { physema. Left lung. T. } 99^{\circ} \mathrm{F} \text {. } \\
\left(37.2^{\circ} \mathrm{C} .\right) \text {; P. } 140 ; \text { R. } 30\end{array}$ & $\begin{array}{l}\text { Slight obstructive } \\
\text { emphysema left } \\
\text { lung. Cervico- } \\
\text { dorsal scoliosis } \\
\text { convexity to } \\
\text { right }\end{array}$ & $\begin{array}{l}\text { Piece of carrot removed from } \\
\text { L.L.L.B. }\end{array}$ & $\begin{array}{l}\text { The diaphragm regained nor- } \\
\text { mal position, but the medias- } \\
\text { tinum did not (owing to } \\
\text { scoliosis). Asymptomatic } \\
6 \text { days }\end{array}$ \\
\hline 6 & 11 & $\mathbf{F}$ & 7 years & $\begin{array}{l}\text { Pneumonia; no complications. Re- } \\
\text { current haemoptyses and wheezing } \\
\text { from age } 4\end{array}$ & $\begin{array}{l}\text { Bronchiectasis } \\
\text { R.L.L. }\end{array}$ & $\begin{array}{l}\text { No evidence of foreign body. } \\
\text { Slight narrowing middle } \\
\text { lobe orifice }\end{array}$ & $\begin{array}{l}\text { Right lower lobectomy. Privel } \\
\text { leaves found in L.L.B. Had } \\
\text { been seen with them in her } \\
\text { mouth when aged } 4\end{array}$ \\
\hline 7 & 4 & F & 1 week & $\begin{array}{l}\text { Severe bouts of coughing and vomit- } \\
\text { ing. Sputum purulent. Treated } \\
\text { for "pneumonia" with some } \\
\text { improvement }\end{array}$ & $\begin{array}{l}\text { Screw in right } \\
\text { bronchus. Atel- } \\
\text { ectasis basal } \\
\text { segments R.L.L. }\end{array}$ & $\begin{array}{l}\text { Screw removed with difficulty, } \\
\text { owing to bronchospasm, } \\
\text { from R.L.L.B. }\end{array}$ & Good recovery \\
\hline 8 & 3 & M & 6 weeks & $\begin{array}{l}\text { While eating peanuts, choked, went } \\
\text { blue, and was gasping for breath. } \\
\text { Father" coughed "him and colour } \\
\text { improved but wheeze persisted. } \\
\text { Bronchoscopy } 9 \text { days later at } \\
\text { another hospital-fragments of nut } \\
\text { removed from R.L.L.B. Initial } \\
\text { improvement, then relapse with } \\
\text { wheeze and stridor, pyrexia, and } \\
\text { purulent sputum }\end{array}$ & $\begin{array}{l}\text { Obstructive } \\
\text { emphysema } \\
\text { right lung (Fig. } \\
\text { 3) }\end{array}$ & $\begin{array}{l}\text { Several pieces of nut removed } \\
\text { from R.L.L. and pus aspir- } \\
\text { ated }\end{array}$ & Complete recovery in 12 days \\
\hline
\end{tabular}


TABLE III.-Summary of Cases-Contd.

\begin{tabular}{|c|c|c|c|c|c|c|c|}
\hline $\begin{array}{l}\text { Case } \\
\text { No. }\end{array}$ & $\begin{array}{c}\text { Age in } \\
\text { Years }\end{array}$ & Sex & $\begin{array}{l}\text { Duration of } \\
\text { Symptoms }\end{array}$ & $\begin{array}{l}\text { History } \\
\text { and Examination }\end{array}$ & $\begin{array}{l}X \text {-ray } \\
\text { Findings }\end{array}$ & $\begin{array}{l}\text { Findings } \\
\text { at Bronchoscopy }\end{array}$ & Comment \\
\hline 9 & 19 & $\mathbf{F}$ & 2 months & $\begin{array}{l}\text { Aspirated piece of coconut. Violent } \\
\text { cough for } 10 \text { minutes, then pain } \\
\text { lower chest on inspiration and } \\
\text { tightness. Three previous broncho- } \\
\text { scopies elsewhere, when pus and } \\
\text { inflamed mucosa only seen }\end{array}$ & $\begin{array}{l}\text { Consolidation } \\
\text { lateral basal } \\
\text { segment, R.L.L. }\end{array}$ & $\begin{array}{l}\text { Right basal stem bronchus } \\
\text { appeared stenosed, owing } \\
\text { to granulation tissue; some } \\
\text { pus }\end{array}$ & $\begin{array}{l}\text { Intensive physiotherapy, pos- } \\
\text { tural drainage, and anti- } \\
\text { biotics - progressive im- } \\
\text { provement. Bronchogram } \\
\text { normal } 1 \text { month later }\end{array}$ \\
\hline 10 & 3 & $\mathbf{M}$ & 5 days & $\begin{array}{l}\text { While eating peanuts, fell. Bout of } \\
\text { coughing and constant wheeze. } \\
\text { Obstructive emphysema left lung. } \\
\text { Bilateral rhonchi }\end{array}$ & $\begin{array}{l}\text { Obstructive } \\
\text { emphysema left } \\
\text { lung }\end{array}$ & $\begin{array}{l}\text { Mucosa of L.M.B. oedema- } \\
\text { tous. No foreign body seen } \\
\text { at first, but gentle blind } \\
\text { instrumentation recovered } 2\end{array}$ & $\begin{array}{l}\text { Immediate } x \text {-ray film showed } \\
\text { mediastinum central and } \\
\text { emphysema cleared. Com- } \\
\text { plete recovery }\end{array}$ \\
\hline 11 & $6: 12$ & $\mathbf{M}$ & 2, & $\begin{array}{l}\text { Swallowed peanut. Coughed and } \\
\text { developed wheeze. Attempts at } \\
\text { disposal by holding him upside } \\
\text { down and shaking, and suction } \\
\text { with endotracheal catheter unsuc- } \\
\text { cessful }\end{array}$ & $\begin{array}{l}\text { Collapse R.L.L. } \\
\text { and obstructive } \\
\text { emphysema }\end{array}$ & $\begin{array}{l}\text { Half shell and several frag- } \\
\text { ments of nut removed from } \\
\text { R.M.B. }\end{array}$ & $\begin{array}{l}\text { Mild laryngotracheitis for } 24 \\
\text { hours, then normal }\end{array}$ \\
\hline 12 & $2 \frac{1}{2}$ & $\mathbf{F}$ & 11, & 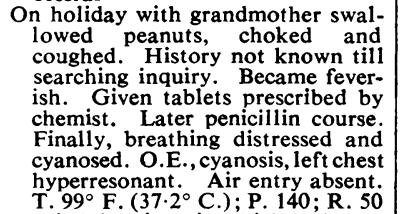 & $\begin{array}{l}\text { Obstructive } \\
\text { emphysema left } \\
\text { lung }\end{array}$ & $\begin{array}{l}\text { Nut removed from L.M.B. } \\
\text { with difficulty due to severe } \\
\text { bronchospasm requiring re- } \\
\text { moval of scope and reinser- } \\
\text { tion }\end{array}$ & $\begin{array}{l}\text { Immediate improvement in } \\
\text { general condition and air } \\
\text { entry left lung, then some } \\
\text { deterioration. Bulk of } \\
\text { foreign body thought to have } \\
\text { been removed; nursed in } \\
\text { steam tent and recovered } \\
\text { completely in } 7 \text { days }\end{array}$ \\
\hline 13 & 11 & $\mathbf{M}$ & 3, & $\begin{array}{l}\text { Inhaled drawing-pin which had been } \\
\text { held in mouth; followed by chok- } \\
\text { ing and pain in right upper chest on } \\
\text { coughing. T. } 100^{\circ} \mathrm{F} .\left(37 \cdot 8^{\circ} \text { C.); }\right. \\
\text { P. } 96 ; \text { R. } 24\end{array}$ & $\begin{array}{l}\text { Obstructive } \\
\text { emphysema left } \\
\text { lung }\end{array}$ & $\begin{array}{l}\text { Pin removed by grasping edge } \\
\text { of head (not stem). It was } \\
\text { dropped in the pharynx and } \\
\text { recovered by direct laryngo- } \\
\text { scopy }\end{array}$ & $\begin{array}{l}\text { Some laryngeal stridor. Recov- } \\
\text { ery in } 5 \text { days }\end{array}$ \\
\hline 14 & 49 & $\mathbf{M}$ & 6, & $\begin{array}{l}9 \text { teeth extracted under inhalation } \\
\text { anaesthesia. "Swallowed" last } \\
\text { tooth. On recovery coughed for } \\
15 \text { minutes, dyspnoeic, chest } \\
\text { wheezy and tight. Pain right lower } \\
\text { chest, worse with breathing. Spu- } \\
\text { tum stained. O.E., orthopnoeic, } \\
\text { slight cyanosis, expiratory wheeze, } \\
\text { dullness; decreased A.E. and V.R., } \\
\text { R.L.L. }\end{array}$ & $\begin{array}{l}\text { Molar tooth in } \\
\text { R.M.B. with } \\
\text { consolidation } \\
\text { lateral subsegs. } \\
\text { of ant. and post. } \\
\text { segs. R.U.L.. } \\
\text { R.L.L., and } \\
\text { L.L.L., and } \\
\text { pneumoconiosis }\end{array}$ & $\begin{array}{l}\text { Tooth in R.M.B. removed } \\
\text { easily }\end{array}$ & Complete recovery in 3 weeks \\
\hline 15 & 9 & $\mathbf{F}$ & 2 , & $\begin{array}{l}3 \text { molar teeth extracted under general } \\
\text { anaesthesia. Immediate dyspnoea } \\
\text { and vomiting. Attempted removal } \\
\text { at another hospital, but lost when } \\
\text { being withdrawn. (Slipped from } \\
\text { right to left side.) T. } 100^{\circ} \text { F. } \\
\left(37.8^{\circ} \text { C.); P. 136; R. } 26\right.\end{array}$ & $\begin{array}{l}\text { Tooth in L.M.B. } \\
\text { Obstructive } \\
\text { emphysema } \\
\text { L.L.L. }\end{array}$ & $\begin{array}{l}\text { Removed from L.M.B.; was } \\
\text { dropped during extraction. } \\
X \text {-ray film revealed position } \\
\text { on right side and successful } \\
\text { removal }\end{array}$ & $\begin{array}{l}\text { Cords a little oedematous } \\
\text { Good recovery }\end{array}$ \\
\hline 16 & 6 & $\mathbf{F}$ & $\begin{array}{l}3 \text { months } \\
2 \text { weekss }\end{array}$ & $\begin{array}{l}\text { Inhaled tooth. Choked and coughed. } \\
\text { Malaise } \\
\text { Rigors }\end{array}$ & $\begin{array}{l}\text { L.U.L. atelecta- } \\
\text { sis and emphy- } \\
\text { sema, L.L.L. }\end{array}$ & $\begin{array}{l}\text { Excessive granulation tissue } \\
\text { in L.M.B. prevented ade- } \\
\text { quate view through infants' } \\
\text { scope and tooth not removed }\end{array}$ & $\begin{array}{l}\text { Postural drainage and physio- } \\
\text { therapy } ; x \text {-ray film before } \\
\text { thoracotomy and broncho- } \\
\text { tomy } 5 \text { days later showed } \\
\text { tooth in stomach-it was } \\
\text { loosened by attempts at } \\
\text { removal, was coughed up } \\
\text { and swallowed }\end{array}$ \\
\hline 17 & 6 & $\mathbf{M}$ & 6 days & $\begin{array}{l}\text { Choked on peanut. Chronic bron- } \\
\text { chitis. Coughing and febrile since. } \\
\text { T. } 100^{\circ} \text { F. }\left(37 \cdot 8^{\circ} \text { C.), signs of con- }\right. \\
\text { solidation R.L.L. and rhonchi } \\
\text { diffusely }\end{array}$ & $\begin{array}{l}\text { Patchy atelectasis } \\
\text { R.L:L. }\end{array}$ & Peanut removed from R.L.L. & $\begin{array}{l}\text { Readmitted a month later with } \\
\text { consolidation post. basic } \\
\text { seg. R.L.L. Re-broncho- } \\
\text { scopy, but no foreign body } \\
\text { seen. Cleared with anti- } \\
\text { biotics }\end{array}$ \\
\hline 18 & 11112 & $\mathbf{M}$ & 3 weeks & $\begin{array}{l}\text { Choked while eating mouthful of } \\
\text { peanuts. Intermittent cough and } \\
\text { wheezing. O.E., diffuse rhonchi, } \\
\text { hyperresonance, and absent air } \\
\text { entry, right lower zone }\end{array}$ & $\begin{array}{l}\text { Obstructive } \\
\text { emphysema } \\
\text { R.L.L. }\end{array}$ & Nut removed from R.L.M.B. & Good recovery \\
\hline 19 & 1 & $\mathbf{M}$ & 1 day & $\begin{array}{l}\text { Swallowed piece of bath sponge. } \\
\text { Expiratory wheeze on exertion. T. } \\
100^{\circ} \text { F. }\left(37.8^{\circ} \text { C. }\right) ; \text { P. } 166 ; \text { R. } 46\end{array}$ & $\begin{array}{l}\text { Atelectasis L.L.L. } \\
\text { with obstruc- } \\
\text { tive emphysema }\end{array}$ & $\begin{array}{l}\text { Carina obscured by sponge; } \\
\text { which obstructed L.M.B. }\end{array}$ & ", \\
\hline 20 & $1 \frac{1}{2}$ & $\mathbf{F}$ & 3 hours & $\begin{array}{l}\text { Swallowed sugar-coated almond. } \\
\text { Coughed and became blue. Cough } \\
\text { and wheeze since. O.E., wheeze; } \\
\text { decreased air entry right chest } \\
\text { anteriorly, rales posteriorly }\end{array}$ & $\begin{array}{l}\text { L.U.L. } \\
\text { Atelectasis R.L.L. } \\
\text { emphysema } \\
\text { R.U.L. }\end{array}$ & $\begin{array}{l}\text { Fragmented foreign body } \\
\text { R.M.B., white nut and } \\
\text { brown skin. Much oedema } \\
\text { of mucosa }\end{array}$ & $"$ \\
\hline 21 & $1 z$ & $\mathbf{F}$ & 5 weeks & $\begin{array}{l}\text { Eating apple and choked. Since then } \\
\text { occasional cough and wheeze on } \\
\text { exertion. O.E., T. } 98^{\circ} \text { F. }\left(36 \cdot 7^{\circ} \text { C. }\right) ; \\
\text { P. } 140 ; \text { R. } 24\end{array}$ & $\begin{array}{l}\text { Emphysema left } \\
\text { lung }\end{array}$ & $\begin{array}{l}\text { Piece of apple size of florin } \\
\text { removed from L.M.B. }\end{array}$ & Recovered 4 days \\
\hline 22 & 1 & $\mathbf{M}$ & 2 & $\begin{array}{l}\text { Choking and cyanosis, while eating } \\
\text { omelette. Later developed wheeze. } \\
\text { Temperature lower after penicillin } \\
\text { course but wheeze remained. T. } \\
102^{\circ} \mathrm{F} .\left(38.9^{\circ} \mathrm{C} .\right)\end{array}$ & $\begin{array}{l}\text { Triangular piece } \\
\text { of shell impac- } \\
\text { ted in upper } \\
\text { trachea }\end{array}$ & $\begin{array}{l}\text { Dificult anaesthesia and in- } \\
\text { strumentation. Cords oede- } \\
\text { matous. Piece of shell } \\
\text { removed through glottis and } \\
\text { several pieces removed on } \\
\text { sucker tip. More pieces } \\
\text { removed through broncho- } \\
\text { scope }\end{array}$ & $\begin{array}{l}\text { Some signs of laryngeal stridor } \\
\text { immediately; one hour later } \\
\text { extreme cyanosis and uncon- } \\
\text { sciousness required tracheo- } \\
\text { tomy. Tube removed 10 } \\
\text { days; recovered in } 1 \text { month }\end{array}$ \\
\hline 23 & $11 / 12$ & $\mathbf{M}$ & 1 week & $\begin{array}{l}\text { Inhaled walnut while on bus. Choked } \\
\text { and became blue. Intermittent } \\
\text { cough siace. O.E., obstructive } \\
\text { emphysema right lung }\end{array}$ & $\begin{array}{l}\text { Atelectasis middle } \\
\text { lobe and ob- } \\
\text { structive em- } \\
\text { physema R.L.L. }\end{array}$ & $\begin{array}{l}\text { Piece of walnut removed from } \\
\text { R.L.M.B. at lovel of middle } \\
\text { lobe orifice }\end{array}$ & Recovery 2 weeks \\
\hline 24 & $111 / 12$ & $\mathbf{F}$ & 7 hours & $\begin{array}{l}\text { Choked on liquorice all-sort. Cough } \\
\text { and wheeze. O.E., generalized } \\
\text { rhonchi. Decreased air entry R.L.L. }\end{array}$ & $\begin{array}{l}\text { Obstructive } \\
\text { emphysema } \\
\text { R.L.L. }\end{array}$ & $\begin{array}{l}\text { No foreign body found. Mod- } \\
\text { erate amount of purulent } \\
\text { secretions aspirated from } \\
\text { lower lobes }\end{array}$ & $\begin{array}{l}\text { Normal } x \text {-ray film following } \\
\text { bronchoscopy. In retrospect, } \\
\text { liquorice had dissolved after } \\
\text { inhalation, causing imme- } \\
\text { diate intense inflammation }\end{array}$ \\
\hline 25 & 13 & $\mathbf{F}$ & 6 weeks & $\begin{array}{l}\text { Accidentally inhaled small gold safety- } \\
\text { pin. No abnormal signs }\end{array}$ & $\begin{array}{l}\text { Open pin, point } \\
\text { up, in R.L.L.B. } \\
\text { Basal mottling }\end{array}$ & $\begin{array}{l}\text { Pin below M.L. orifice, with } \\
\text { point embedded in mucosa. } \\
\text { Several attempts at removal } \\
\text { unsuccessful }\end{array}$ & $\begin{array}{l}\text { Thoracotomy and broncho- } \\
\text { tomy. Head of pin lying } \\
\text { below apical seg. of R.L.L.B, } \\
\text { It was grasped and the pin } \\
\text { gradually removed by } \\
\text { straightening it out. Un- } \\
\text { eventful recovery }\end{array}$ \\
\hline
\end{tabular}


leaving the table: a useful trick in the case of children is to blow cigarette smoke over the patient's face.

After bronchoscopy all these patients are treated on return to bed with postural drainage, physiotherapy, and a suitable antibiotic. If removal of a foreign body has failed owing to its impaction in granulation tissue the patient is sent back to bed and treated in the same way as the others. This may allow the oedema to subside and permit a better view at the next attempt. Occasionally a small object which has

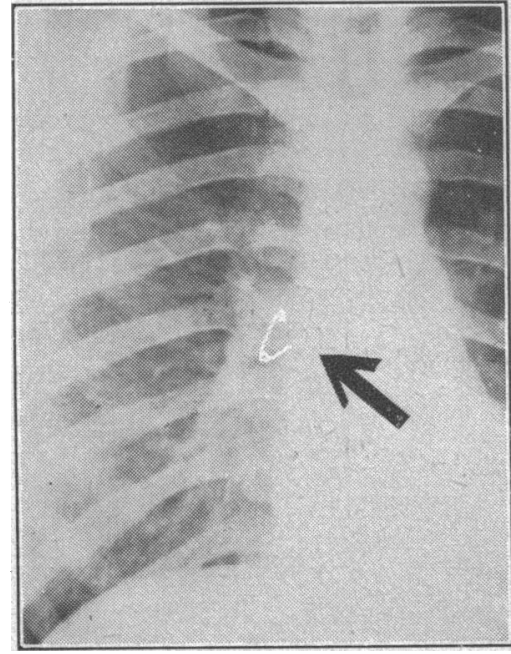

Fig. 5.-Case 2. Postero-anterior ches radiograph. Open safety-pin in right main bronchus.

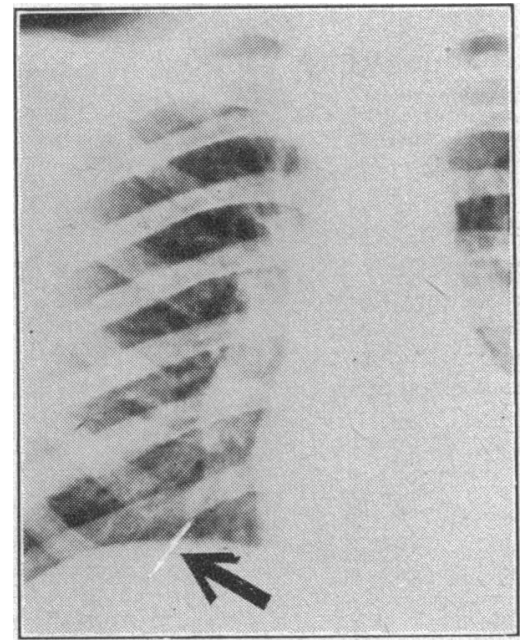

Fig. 6.-Case 1. Postero-anterior chest radiograph. Pin in posterior basal segment of right lower lobe. been loosened by attempts to grasp it will be coughed up (Case 16). Small children should be nursed in a steam tent, and a close watch maintained for signs of laryngeal obstruction, in which case a tracheotomy may be indicated (Case 22).

A foreign body which has not been s u c c e s f u 11 y removed via the natural passages should be removed at thoracotomy by bronchotomy (Fig. 6 and Case 25). If this aggressive course is not followed, irreversible changes will take place and lung parenchyma will subsequently b e sacrificed (Case 6).

The removal of metallic objects by magnets appears attractive in theory, but in practice has dis a dvantages (Jackson and Jackson, 1950). It is not possible to know beforehand whether an object will be magnetic unless an identical one is produced for testing. Iron, steel, and cobalt are not a $1 \mathrm{w}$ a y s magnetic, and the magnetism of alloys depends on the amount of heat received during the processing. Furthermore, the power of a magnet is inversely proportional to the square of the distance from its object, and, while intervening tissues do not impair magnetism per se, their presence makes contact difficult. On the whole, metallic objects in main bronchi are more easily removed by direct methods, and in deeply placed situations will usually require bronchotomy.

\section{Prevention}

Loose teeth in an anaesthetized patient should always be carefully watched. Children should not be allowed to eat nuts until they have a full set of teeth, or, if they are, the nuts should be finely ground. Small objects such as pins, buttons, and coins should not be left within an infant's reach. A parent should not set a bad example for a child by holding tacks and pins in the mouth. Children should not be allowed to play while eating, or eat too quickly without proper mastication. The adage is still true that if nothing except food was put in the mouth the inhalation of a foreign body would be a rare accident.

\section{Summary}

Experience has been gained with 25 cases of inhaled foreign body, mostly in children. The early history of an inhaled foreign body is often missed ; the later results may simulate almost any chest disease. The diagnosis is made from the history and the presence on clinical examination of atelectasis or obstructive emphysema, and from chest radiography. The importance of early removal of the foreign body by a team consisting of an experienced bronchoscopist and an experienced anaesthetist is stressed. The essential part of the anaesthetic is surface analgesia of the trachea and bronchi. If removal by bronchoscopy fails, thoracotomy and bronchotomy is justified, with the sacrifice of any destroyed lung. The majority of inhalation accidents may be prevented : nuts should not be given to young children who have no molars, small objects must be kept out of an infant's reach, and care should be taken with loose teeth in an anaesthetized patient.

We should like to thank $\mathrm{Mr}$. Dillwyn Thomas, consultant thoracic surgeon, Welsh Regional Hospital Board, under whose care these patients were admitted, for his stimulation, criticism, and interest in this study. Mr. W. P. Cleland has kindly given permission to publish Case 25. We are grateful to Mrs. B. Marshall for photography, Miss Juliet Hilary-Jones for secretarial assistance, and Mr. K. Hillard for drawing Fig. 1.

\section{REFERENCES}

Asherson, N. (1953). Brit. J. Tuberc., 47, 209

Asherson, $\mathrm{R}$. (1948). Diseases of the Chest, Livingstone, Edinburgh. Jackson, C. and Jackson, C. L. (1950). Broncho-Oesophagology. Saunders, Philadelphia and London

Mushin, W. W. and Lake, R. H. N. (1951). Anaesthesia, 6, 88.

Registrar-General (1954). Statistical Review of England and Wales, Part 1 , p. 187. H.M.S.O., London.

\section{TRACHEOSTOMY, AND MANAGEMENT OF THE UNCONSCIOUS PATIENT}

BY

JOHN ANDREW, M.B., F.R.C.S.

Senior Registrar, Department of Neurological Surgery, St. Bartholomew's Hospital, London

In recent years the indications for tracheostomy have been extended to include the management of tetanus, respiratory paralysis, and the unconscious patient. This simple operation has gained a highly valued place in neurosurgical practice, where the problem of maintaining a clear airway in comatose patients is often encountered. In the last four years in the Department of Neurological Surgery of St. Bartholomew's Hospital 16 tracheostomies have been performed. Selected cases are reported to illustrate the varying indications for the procedure. The mechanism whereby the normal gaseous exchange in the lungs is interfered with in these cases is discussed. The technique for ensuring adequate pulmonary ventilation and a satisfactory intracranial circulation in unconscious patients is also described.

\section{Technique of Tracheostomy}

It must be emphasized that so far as is possible this operation should be carried out as an elective procedure. It may be satisfactorily performed under local 